\title{
Evaluation of Dimensions and Drainage Performance Office in the Aceh Tamiang Area Kuala Simpang
}

\author{
Kamaluddin Lubis \\ Faculty of Engineering, Universitas Medan Area, Indonesia \\ Email: Klubis250@gmail.com
}

\begin{abstract}
:
The Aceh Tamiang office area is one of the office areas in Kuala Simpang which consists of various offices in the Aceh Tamiang area. The purpose of this research is to identify the drainage condition of the existing primary drainage channel which accommodates runoff discharge, the shape and direction of the flow in the inundation channel in the Aceh Tamiang Kuala Simpang office area, which is expected to help solve the problem offlooding in the $832 \mathrm{m3} / \mathrm{second}$. And for the channel capacity in this primary drainage drainage of $0.829 \mathrm{m3} / \mathrm{sec}$, the value is smaller than the planned flood discharge (Qr). Rainfall intensity (I) of 126,432 $\mathrm{mm} / \mathrm{hour}$. The plan flood discharge (Qr) for a 5-year return period yields 2,551 $\mathrm{m3} /$ second and the value for channel discharge capacity (Qs) is obtained from the calculation of 2,216 m3/second. This value is smaller than the value of the planned flood discharge. area. From the results of research conducted by the Aceh Tamiang Kuala Simpang office area is a location with a fairly high degree of rainfall, with a rainfall intensity (I) of 126,432 $\mathrm{mm} /$ hour and a flood discharge plan for a 5-year return period obtained a result of 0 .
\end{abstract}

Keywords:

hydrology; determination of maximum rainfall; dimensions; performance of roadways

\section{Introduction}

The Aceh Tamiang office area is one of the office areas in Kuala Simpang which consists of various offices in the Aceh Tamiang region. Various building, drainage, or other building facilities must need maintenance and repair so that existing buildings and facilities are maintained, one of which is the existing drainage buildings in the area. With the continuing development of the area around the area or outside the area, the growth of housing development in the surrounding community will certainly have a lot of impact on increasing the water discharge that will be channeled into the existing drainage.

Changes in land use in the surrounding area due to housing growth is one of the main triggers for increased drainage discharge or other factors, previously there were still many small forest areas as well as land areas in the form of swamps, usually the location of the land was used as a rainwater catchment area so that the flood discharge was mainly rain can be stored temporarily, by itself the water does not directly enter the drainage of the area so it is avoided from the danger of flooding, especially when it rains.

Land disputes and conflicts are complex and multidimensional problems. Therefore, efforts to prevent, handle and resolve must take into account various aspects, both legal and non-legal. Often the handling and resolution of land disputes and conflicts is faced with dilemmas between different interests that are equally important. Finding a balance or win-win solution for conflicts that already occur clearly requires effort that is not easy. Legislation that applies to land acquisition does not accommodate the paradigm of community development that is just, prosperous, and prosperous. The discrepancies between the forms of policy regulation often lead to disputes or conflicts. (Isnaini et al, 2020) 
In general, land area has a direct effect on production, if land area increases, it will automatically increase production. However, at a certain time the planting area and production will not affect directly if there are several factors in it including planting age which directly affects production. (Hasibuan, et al. 2020)

The channel or road drainage is to function as a means of channeling waste water and also as channeling rainwater to avoid the danger of flooding, changes in climate, weather and high rainfall often occur without being able to predict when it occurs, increasing water discharge often in drainage results in flooding in the area, Incidents like this often occur that drainage cannot accommodate rainwater and overflows from outside the drainage, causing flooding. Many trash found or do not have a channel to accommodate water discharge is also a trigger for flooding, but usually floods that occur was in that area happened a long time, This is because the area is a local contour area which is lower than the surrounding area so that flooding generally occurs outside the area such as the existing channel on the main city road.

The need for the construction of final waster primary drainage, which is a water reservoir, really needs to be planned with a sustainable concept, which is something that needs to be planned so that the primary drainage of final disposal is maintained and maintained so that it functions as a planned area to be protected from the danger of flooding.

Drainage which comes from the English language drainage means to drain, drain, remove, or divert water. In the field of civil engineering, in general, drainage can be defined as an action to reduce excess water, which comes from rain, seepage, or excess irrigation water from an area / land, so that the function of the area / land is not disturbed. Drainage is also defined as an effort to control the quality of groundwater in terms of sanitation. So, it concerns not only surface water but also groundwater

Drainage is an action to reduce excessive water, both surface water and underground water. Excessive water which is generally in the form of stagnation is called flooding. Meanwhile, according to Mulyono. Drainage is a natural process, adapted by humans for their own purposes, directing water in time and space by manipulating the water level. The drainage system has been needed since several centuries ago, such as in $300 \mathrm{BC}$ roads at that time were built at higher elevations in order to avoid runoff on the road.

\section{Research Method}

\subsection{Drainage Network System}

The drainage network system is part of the infrastructure in an area, drainage is included in the water infrastructure group in the regional infrastructure group, besides that there are road groups, transportation groups, waste management groups, city building groups, energy groups and telecommunication groups.

Ideally, in the General Regional Spatial Plan (RTRW) and / or the City Infrastructure Network Master Plan. The city drainage network system must be developed starting from wastewater (sewage) that enters (surface drainage / ditch), continues into the ground again, or is directed to flow into rivers (sewers), and empties into the sea or flows in to the ground. holding pond.

In general, the road drainage network system approach begins by plotting the road routes to be reviewed on a topographic map to determine the service area so that it can 
predict the need for the placement of road drainage buildings and other supports by paying attention to the existence of the environment. The point is to calcula te the flow rate, calculate the dimensions of the canal, the slope of the channel and other water bodies and pay attention to other factors that support the drainage network system.

Evaluation of the drainage network system is an attempt to measure the achievement of the results planned in advance, in this case the road drainage network system planning to drain rainwater or waste water from upstream to downstream. Evaluation of the road drainage network system includes road topography, flow direction, channel discharge, channel dimensions, channel slope and other water body structures as well as factors that support the running of the drainage network system where the evaluation is intended to be a feedback for future planning.

\subsection{Highway Drainage}

In essence, road drainage (roadside canal) functions as a surface channel to drain surface water from the road body, assuming it accommodates the catchmen area in the limited surrounding environment, including drainage on slopes or hills on the side of the road.

The main principle is to provide facilities in the form of canals and complementary buildings, which are placed on both sides of the roadside, and / or on the road media and / or in the channel building under the road surface, which functions to drain rainwater that falls around the surface or road body ( limited catchment area) more quickly (there is no standing water), and / or there is underground water that must be channeled so that road damage (structure / body), such as potholes, collapsed roads that can endanger traffic can be avoided, and roads are properly maintained. structure and function properly. The purpose of making road drainage channels is as follows: Prevent the accumulation of rainwater (puddles) that can disrupt transportation. Maintain the soil water content of the road body / foundation for a long life. Prevents the loss of strength of the cover materials, Reduces changes in subgrade volume. Prevents damage due to fine sand on rigid pavements and prevents waves on flexible pavements Prevents soil erosion Prevents slope slide. And add to the beauty of the city.

\subsection{Hydraulics Aspect}

The planned discharge is the debit which is estimated to be the maximum discharge that will be flowed by the drainage channel to be used as a benchmark to dimension the drainage channel so that inundation does not occur. For urban and road drainage, the planned discharge is set for a maximum flood discharge period of 5 years based on considerations. The risk of inundation arising from rain is relatively small when compared to flooding caused by overflowing a river.

The most economical form of conduit is one that can pass the maximum flowrate for a certain wet cross-sectional area, roughness and bottom slope. Based on the continuity equation, it is clear that for a fixed cross-sectional area, the maximum discharge is achieved if the flow velocity is maximum.

Measurement of the dimensions of the channel, namely the channel base width (b), the channel top width (B), the slope of the channel side (m), guard height (f), channel wet height (h) and channel slope (S). By knowing the channel bottom width and wet height of the channel above, it can be obtained the wet cross-sectional area of the channel (A), the wet circumference of the channel $(\mathrm{P})$ and the hydraulic radius $(\mathrm{R})$. Based on the formula obtained from the book Creative Planning (KP), it can be shown as below: 


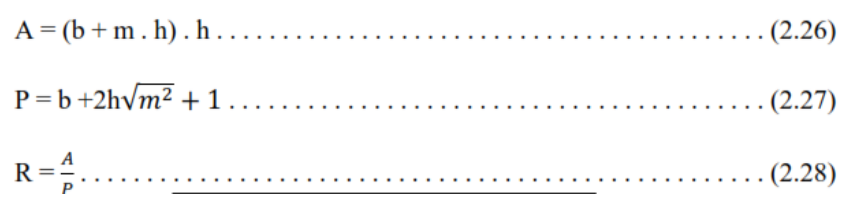

Figure 1. Square Channel Section

In the channel planning in the field, a square channel is used where the relationship between the planned discharge and the surface dimensions is determined based on the Manning formula, namely:

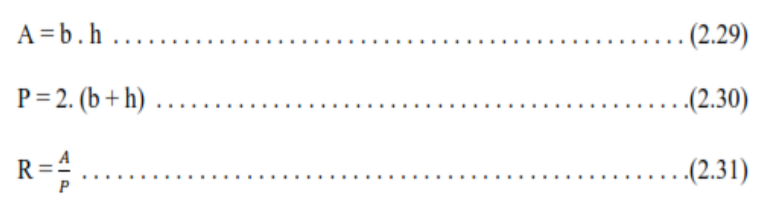

\section{Research Method}

The research location is the Aceh Tamiang Office area, this area is a joint office area in Aceh Tamiang Kuala Simpang, Aceh Province.

The research method used is descriptive quantitative research method, which is the method of calculation and elaboration of the results of field data processing from each location under review.

The data analysis techniques performed in this study were as follows:

- Monthly rainfall data for the last ten years were obtained from the Aceh Tamiang Public Works and Public Housing (PUPR) Office

- Analyze the maximum rainfall in the return period (tr) years using the Al-Jabar (Arimmatik) average formula.

- Determine the distribution of the frequency of rainfall to be selected (Normal Distribution, Normal Log, Gumbel, and Log Person III).

- Test the frequency distribution of the maximum planned rainfall with the Chi-Square test and the suitability test.

- Calculating the intensity (I) of average rainfall using the Van Breen formula.

- Calculating Concentration Time (tc) and Channel Slope (S)

- Calculating Area of Flow (A) and Coefficient of Runoff (C)

- Calculating the Planned Flood Discharge (Qr) with the Rational Formula with a return period of 5 years.

- Calculating Flow Velocity (V)

- Calculating the capacity (Qs) of water discharge from existing drainage channels.

- Check the carrying capacity (Qs> Qr)

- Determine the factors that cause standing water or flooding and then determine direction of water runoff flow.

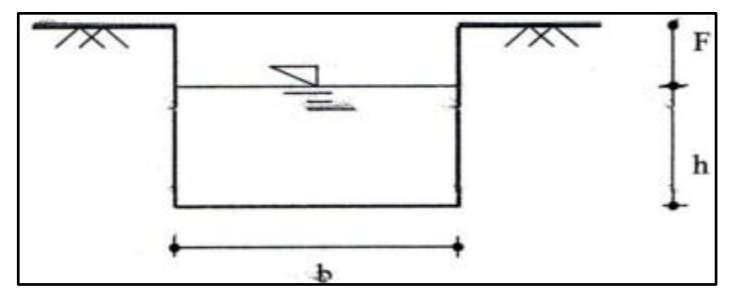


Calculation of the maximum annual rainfall for the area based on rainfall data using the algebraic average formula. The formula is used as follows:

$$
\mathrm{R}=1 / \mathrm{n}(\mathrm{R} 1+\mathrm{R} 2+\mathrm{R} 3+\mathrm{Rn})
$$

Furthermore, the average rainfall data is obtained from the time period each year, then then look for the maximum average rainfall area with the formula for algebraic average again. The following are the results of the calculation of the maximum regional rainfall from 2008 to 2017, as follows:

Table 1. Regional Average Annual Rainfall 2008-2017

\begin{tabular}{ccccc}
\hline Year & St. Socfindo & StSisiran & St.PTPN.I & $\begin{array}{c}\text { Rainfall } \\
\text { Maximum }\end{array}$ \\
\hline 2008 & 732 & 555 & 724.4 & 670.47 \\
2009 & 585 & 585 & 582 & 584.00 \\
2010 & 302 & 302 & 304.2 & 302.73 \\
2011 & 318 & 318 & 442 & 359.33 \\
2012 & 186 & 374 & 193 & 251.00 \\
2013 & 303 & 452.5 & 355 & 370.17 \\
2014 & 447 & 499 & 637 & 527.67 \\
2015 & 827 & 786 & 494 & 702.33 \\
2016 & 332 & 354 & 263 & 316.33 \\
2017 & 243 & 371 & 394 & 336.00 \\
& & & $\Sigma$ & 4420.03 \\
\hline
\end{tabular}

Table 2. Average Annual Regional Rainfall 2008-2017

\begin{tabular}{ccccc}
\hline Month & St. Socfindo & St. Comb & St. PPTN.I & $\begin{array}{c}\text { Rainfall } \\
\text { Maximum }\end{array}$ \\
\hline Jan & 82 & 786 & 637 & 750.00 \\
Feb & 73 & 555 & 724.4 & 670.47 \\
Mar & 25 & 338 & 229 & 275.00 \\
Apr & 036 & 374 & 289.1 & 341.37 \\
May & 21 & 308 & 224 & 250.33 \\
June & 10 & 228 & 147 & 161.00 \\
July & 27 & 258.5 & 147 & 225.83 \\
Augs & 12 & 199 & 164 & 163.33 \\
Sept & 16 & 602 & 221 & 329.33 \\
Oct & 24 & 730 & 349 & 440.67 \\
Nov & 20 & 448 & 292 & 314.00 \\
Des & $\hat{1}$ & 452.5 & 320.6 & 404.37 \\
& $\hat{4}$ & & $\Sigma$ & 4325.70 \\
& $n$ & & & \\
\hline
\end{tabular}




\subsection{Frequency Distribution Analysis}

In determining the frequency distribution of rainfall, various methods of rainfall distribution analysis can be carried out. Referring to the existing theoretical basis in this study, the analysis of the frequency of rainfall was carried out with the Normal distribution, Normal Log, Log Person III and Gumbel using the results of previous calculations.

Furthermore, the data is used in statistical analysis for Normal distribution, Log Pearson, Log Pearson III and Gumbel. Furthermore, the frequency distribution is selected in accordance with the value of the data suitability test by Chi Cudrate test.

Determine the value of the frequency factor $(\mathrm{KT})$ which can be seen in the table of the value of the Gauss reduction variable.

\section{$X T T X X=T . S S$}

So for the return period 2,5,10, 25, and 50, the following calculation results are obtained:
a. $\mathrm{T} 2=442.003+(0 \times 164.10)=442.00 \mathrm{~mm}$
b. $\mathrm{T} 5=442.003+(0.84 \times 164.10)=579.85 \mathrm{~mm}$
c. $\mathrm{T} 10=442,003+(1.28 \times 164.10)=652.06 \mathrm{~mm}$
d. T25 $=442,003+(1.71 \times 164.10)=722.62 \mathrm{~mm}$
e. $\mathrm{T} 50=442,003+(2.05 \times 164.10)=778.42 \mathrm{~mm}$

From the calculations above, a graph can be drawn as below:

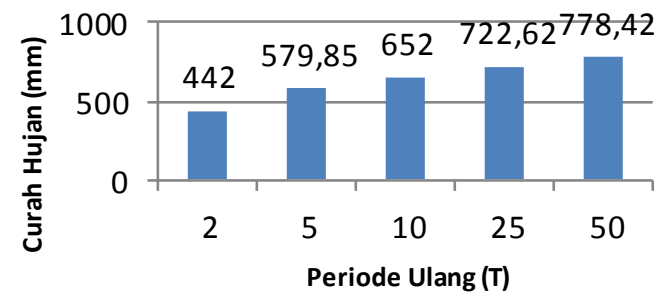

Figure 2. Normal Distribution Rainfall Graph

\subsection{Normal Log Distribution}

Next, analyze the Log Normal distribution by paying attention to the $\log X$ value and $\mathrm{KT}$ value as in the normal distribution, namely:

$$
Y=Y Y+K T \cdot S
$$

Meanwhile, for the rainfall plan obtained:

$$
X=\mathbf{1 0}^{Y T}
$$

For return periods of $2,5,10,25$ and 50, the following calculation results are obtained:
a. $\mathrm{Y} 2=2.6193+(0 \times 0.158)=2.62$
$X=102.6193=416.18 \mathrm{~mm}$
b. $\mathrm{Y} 5=2.6193+(0.84 \times 0.158)=2.75$
$X=102.7520=564.54 \mathrm{~mm}$
c. $\mathrm{Y} 10=2.6193+(1.28 \times 0.158)=2.82$
$X=102.8215=662.29 \mathrm{~mm}$ 
d. $\mathrm{Y} 25=2.6193+(1.71 \times 0.158)=2.89$

$\mathrm{X}=102.8895=774.16 \mathrm{~mm}$

e. $\mathrm{Y} 50=2.6193+(2.05 \mathrm{x} 0.158)=2.94$

$\mathrm{X}=102.9432=875.84 \mathrm{~mm}$

From the above calculations, the results can be described with a graph as below:

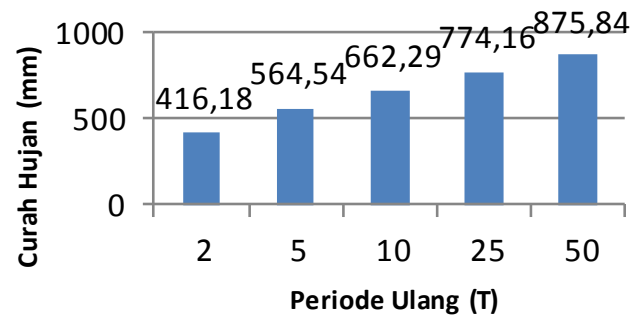

Figure 3. Rainfall Distribution Graph Normal Log

\subsection{Distribution Log Person III}

Obtained the slope coefficient $(\mathrm{G})$ of 0.352 rounded to 0.36 , then the value of the price table for the return period $\mathrm{T}$ can be found using interpolation. The following is a table of the $\mathrm{G}$ coefficients with the $\mathrm{K}$ values as follows:

Table 3. K Value of Firmness Coefficient

(G) Return Period (T)

\begin{tabular}{llll}
\hline \multicolumn{3}{l}{ No. Return Period (T) } & Coefficient (G) \\
\hline 1. & 2 & 0.36 & -0.0396 \\
2. & 3 & 0.36 & 0.8272 \\
3. & 10 & 0.36 & 1,3042 \\
4. & 25 & 0.36 & 1,8304 \\
5. & 50 & 0.36 & 2,1794 \\
\hline
\end{tabular}

After calculating the value of the firmness coefficient $(\mathrm{G})$ with return period values of $2,5,10,25$, and 50 years with a value of $\mathrm{K}$ price, then calculate the frequency of rainfall with the Log Pearson III formula:

\section{$\log X T=\log X+K . S$}

So, here is the Log Pearson III calculation for each return period, namely:

a. $\log \mathrm{X} 2=2.619+(-0.0396 \times 0.158)=2.61$

$\mathrm{X} 2=102,613=410,24 \mathrm{~mm}$

b. $\log X 5=2.619+(0.8272 \times 0.158)=2.75$

$\mathrm{X} 5=102,750=561.92 \mathrm{~mm}$

c. $\log \mathrm{X} 10=2.619+(1.3042 \times 0.158)=2.82$

$\mathrm{X} 10=102,825=668.14 \mathrm{~mm}$

d. $\log X 25=2.619+(1.8304 \times 0.158)=2.91$

$\mathrm{X} 25=102.908=808.74 \mathrm{~mm}$

e. $\log X 50=2.619+(2.1794 \times 0.158)=2.96$

$\mathrm{X} 50=102.963=917.96 \mathrm{~mm}$ 
From the above calculations, it can be seen that the graphic results of the calculation of rainfall with the Log Pearson III distribution in Figure 3 below:

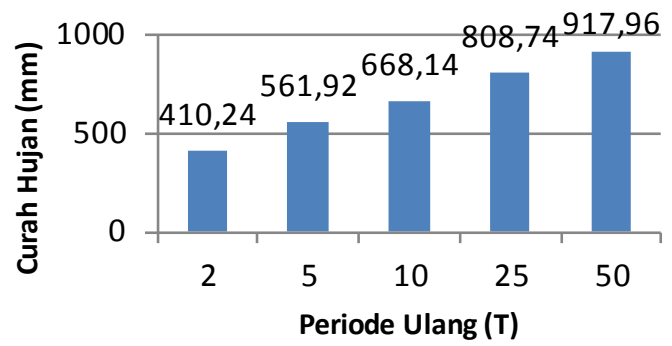

\section{Figure 4. Rainfall Distribution Graph Pearson Log III}

After getting the average value of rainfall and its standard deviation, the values for Reduced Mean (Yn), Reduced Standard Deviation (Sn) and Reduced Variate (Ytr) are obtained in table 4.16, the values of Ytr, Yn, and $\mathrm{Sn}$ are obtained as follows:

Table 4. Yn, Sn, and Ytr values for Return Period (T)

\begin{tabular}{|c|c|c|c|c|c|}
\hline No. Retur & n Period (T) & Number of Years (N) & Yn & Sn & Ytr \\
\hline 1. & 2 & 10 & 0.4952 & 0.9496 & 0.3668 \\
\hline 2. & 5 & 10 & 0.4952 & 0.9496 & 1,5004 \\
\hline 3. & 10 & 10 & 0.4952 & 0.9496 & 2,251 \\
\hline 4. & 25 & 10 & 0.4952 & 0.9496 & 3,1993 \\
\hline 5. & 50 & 10 & 0.4952 & 0.9496 & 3,9028 \\
\hline
\end{tabular}

Next, calculate the planned rainfall for the return period of 2, 5, 10, 25 and 50 years which are planned after getting the Yn, Sn, and Ytr values with the Gumbel distribution as follows:

$$
X_{t r}=X+\left(\frac{Y_{t r}-Y_{n}}{s n} . S\right)
$$

The following is the graph of the calculation of rainfall using the Gumbel distribution in Figure 4.4 below:

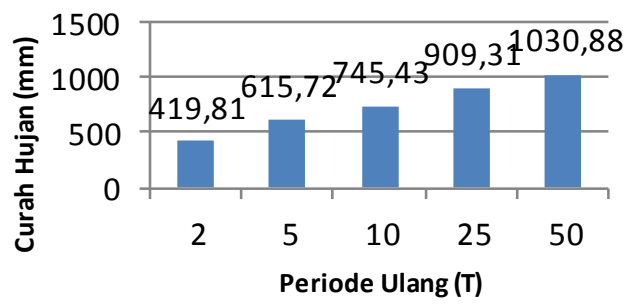

Figure 5. Rainfall Graph Gumbel distribution 
This dispersion test is carried out based on the calculations below, so the results of the dispersion test are as follows:

Table 5. Dispersion Test Value of Rainfall Frequency Distribution

\begin{tabular}{|c|c|c|c|c|}
\hline No. & $\begin{array}{l}\text { Type } \\
\text { Distribution }\end{array}$ & Terms & Calculation & Conclusion \\
\hline \multirow[t]{2}{*}{1} & Normal & $\mathrm{Cs}=0$ & 0.606 & Go back \\
\hline & & $\mathrm{Ck}=3$ & 19,024 & Go back \\
\hline \multirow[t]{2}{*}{2} & Normal Log & $\operatorname{Cscv} 3+3 \mathrm{cv}=0.162$ & 0.311 & Go back \\
\hline & & $\mathrm{Ck}=\mathrm{Cv} 3+6 \mathrm{cv} 6+15 \mathrm{cv} 4+16 \mathrm{cv} 6+3=3,047$ & 18,173 & Go back \\
\hline \multirow[t]{2}{*}{3} & Pearson Log Iii & $\mathrm{Cs}=0$ & 0.311 & Fulfill \\
\hline & & $\mathrm{Ck}=0$ & 18,173 & Fulfill \\
\hline \multirow[t]{2}{*}{4} & Gumbel & $\mathrm{Cs}=1.14$ & 0.606 & Go back \\
\hline & & $\mathrm{Ck}=5,4$ & 19,024 & Go back \\
\hline
\end{tabular}

\subsection{Pearson Log Distribution Chi Square Test III}

The purpose of this Chi-square test is to determine whether the distribution equation that has been selected can represent the distribution of the sample data being analyzed. The determination of this decision uses the parameter $\mathrm{X} 2$, which can be calculated using the following formula:

$$
X^{i}=\sum_{i=1}^{i} \frac{(o i-E i)^{2}}{E i}
$$

Table 5. Test Values of the Quadratic Distribution Log Pearson III

\begin{tabular}{|c|c|c|c|c|}
\hline Nilai the limit of each class & Oi & $\mathrm{Ei}$ & $(\mathrm{Oi}-\mathrm{Ei}) \wedge 2$ & $(\mathrm{Oi}-\mathrm{Ei}) \wedge 2 / \mathrm{Ei}$ \\
\hline $2.3997<\mathrm{Xi}<2.5486$ & 4 & 2.5 & 2.25 & 0.9 \\
\hline $2.5486<\mathrm{Xi}<2.6976$ & 2 & 2.5 & 0.25 & 0.1 \\
\hline $2.6976<\mathrm{Xi}<2.8465$ & 2 & 2.5 & 0.25 & 0.1 \\
\hline $2.8465<\mathrm{Xi}<2.9955$ & 2 & 2.5 & 0.25 & 0.1 \\
\hline Frilah & 10 & 10 & 3 & 1,2 \\
\hline
\end{tabular}

By using the real level of testing $(\alpha)=0.05$ or the equivalent of $5 \%$ and $\mathrm{DK}=1$, the distribution of chi cudrat Xtabel2 = was 3,841. From the results of the above calculations, it is obtained X 2 count of $1.2<\mathrm{X} 2$ table $=3.841$, so that it can be decided that the method used for the selection of planned rainfall is the distribution method.

Pearson III logs and tested conditions. Furthermore, the value is $561.92 \mathrm{~mm}$, a 5 year return period to calculate Rainfall Intensity 


\subsection{Planned Flood Discharge (Qr)}

The planned flood discharge is the maximum planned discharge in a river or other water structure with a certain return period that can be channeled by the channel without endangering the surrounding environment and the stability of the channel. The discharge plan is carried out by analyzing the maximum rainfall data at the rainfall station then observing and measuring directly the location of the drainage channel.

\subsection{Area (A) and Flow Coefficient (C)}

In this research on the road drainage network system, the flow coefficient (C) refers to SNI 03-3424-1994 concerning the Road Surface Drainage Planning Procedure, so the flow coefficient $(\mathrm{C})$ is obtained to connect certain ground conditions.

Meanwhile, for the planning of the flow area for the highway, the calculation is as follows, namely the Total Area (A) in the calculation above is around $31.595 \mathrm{~m} 2$.

Next, calculate the combined coefficient value $(\mathrm{Cw})$ which is calculated as follows:

$$
\begin{gathered}
\mathrm{Cw}=\left(\left(\mathrm{C} \_1 \text { A_1 }\right)+\left(\mathrm{C} \_2 \text { A_2 }\right)+\left(\mathrm{C} \_3 \text { A_3 }\right)+\left(\mathrm{C} \_4 \text { A_4 }\right)+\cdots+\left(\mathrm{C} \_\mathrm{n}\right.\right. \\
\mathrm{xA} \text {-n })) /\left(\mathrm{A} \_1+\mathrm{A} \_2+\mathrm{A} \_3+\mathrm{A} \_4+\left[(. .+\mathrm{A}) \_\mathrm{n}\right)\right.
\end{gathered}
$$

The combined flow coefficient $(\mathrm{C})$ is 0.750

\subsection{Calculation of Planned Flood Discharge (Qr)}

The calculation of the flood discharge plan used in this study is to use the rational flood discharge method with a return period of 5 years.

$$
\text { Qr }=0.2778 . C I A(\text { Unit Km2) }
$$

Previously, the flow efficiency value $(\mathrm{C})$ was 0.748 . The value of rainfall intensity (I) was $126.432 \mathrm{~mm} /$ hour with a return period of 5 years and flow area (A) $30.082 \mathrm{~m} 2$. follows:

Then it can be calculated the planned flood discharge for the 5 year return period as

Qr $\quad=0.2778 .0 .750 .126,432.0 .031595=0.832 \mathrm{~m} 3 / \mathrm{second}$

\subsection{Flow Velocity Calculation (V)}

The formula for calculating the flow velocity in a channel uses the following formula:

$$
V=\frac{1}{n} \cdot R^{\frac{2}{3}} \cdot S^{\frac{1}{2}}
$$

To obtain the hydraulic radius $(\mathrm{R})$, the wet cross-sectional area and perimeter values are required.

The cross-sectional area (A) uses the following formula:

$$
\mathrm{A}=\mathrm{bxh}=1.2 \times 1=1.2 \mathrm{~m} 2
$$

The wet circumference $(\mathrm{P})$ is obtained by the following formula:

$$
\mathrm{P}=2 .(\mathrm{b}+\mathrm{h})=2 \cdot(1,2+1)=4.4 \mathrm{~m}
$$

It can be calculated the value of the hydraulic formula $(\mathrm{R})$ of: 
$R=\frac{A}{P}=\frac{1,2}{4,4}=0,27 \mathrm{~m}$

For the freeboard height of:

$w=\sqrt{0,5} \cdot h=\sqrt{0,5} \cdot 1,2=0,7071 m$

Thus, the flow rate $(\mathrm{V})$ for the drainage can be calculated as follows:

$V=\frac{1}{n} \cdot R^{\frac{2}{3}} \cdot S^{\frac{1}{2}}=\frac{1}{0,025} \cdot 0,27^{\frac{2}{3}} \cdot 0,0017^{\frac{1}{2}}=0,691 \mathrm{~m} / \mathrm{det}$

Flow velocity (V) from the calculation results obtained $0.691 \mathrm{~m} / \mathrm{sec}$. Meanwhile, the permissible flow rate for masonry is $1.5 \mathrm{~m} / \mathrm{sec}$. This means that a flow velocity (V) of 0.691 $\mathrm{m} / \mathrm{s}$ can be used.

\subsection{Channel Discharge Capacity (Qs)} formula:

The calculation of the channel discharge capacity can be calculated with the following

$$
Q_{S}=V \cdot A=0,691 \cdot 1,2=0,829 \mathrm{~m}^{3} / \text { det }
$$

From the results of the above calculations, it is found that the channel discharge capacity (Qs) is $0.829 \mathrm{~m} 3$ / second, the value is less than the planned flood discharge (Qr) of $0.832 \mathrm{~m} 3 /$ second. This proves that the existing drainage canal is still able to accommodate the planned flood discharge, but the problem is that in the existing channel there are lots of garbage piles, sunken road conditions, inappropriate flow direction and less exhaust holes from the road to the existing channel.

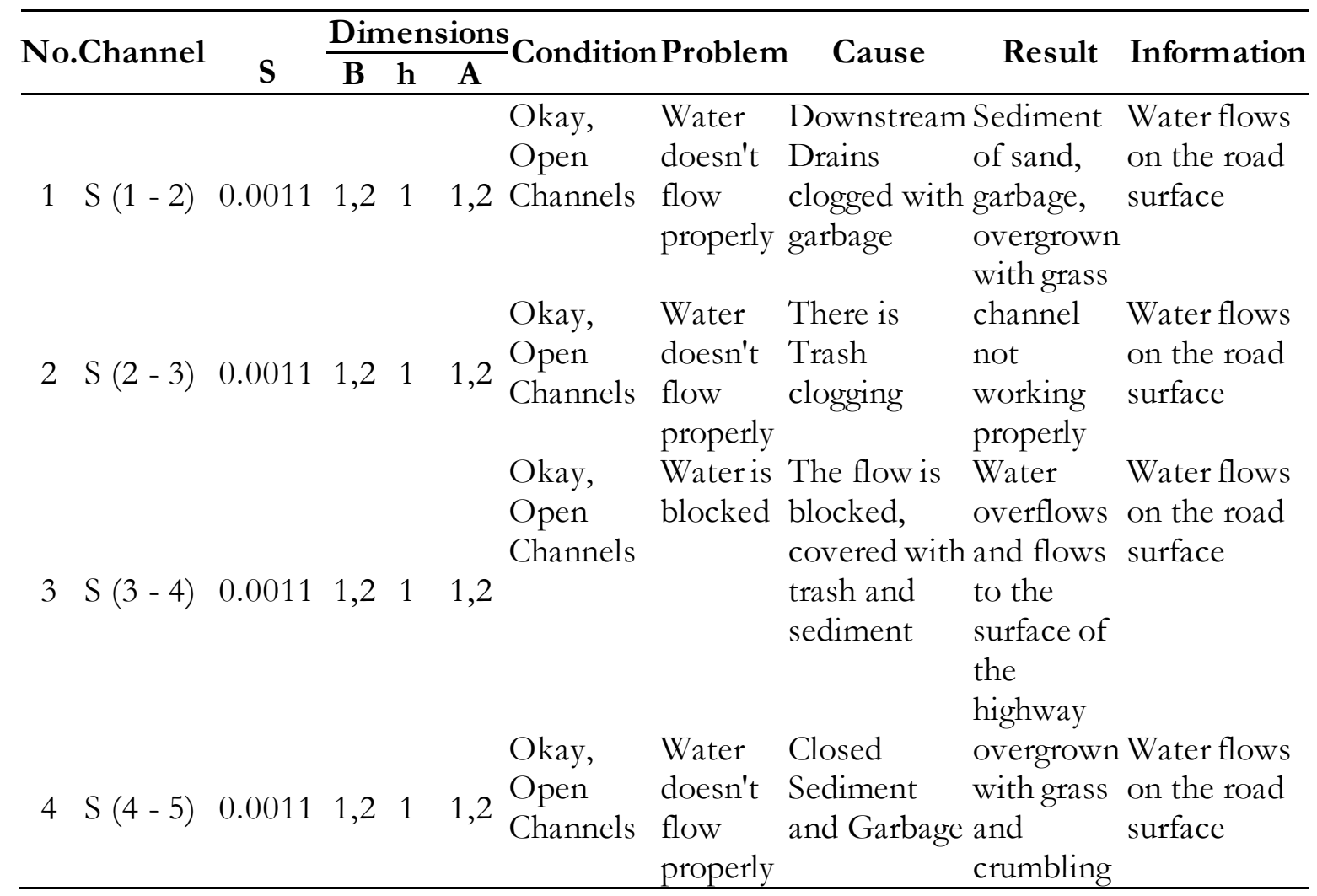




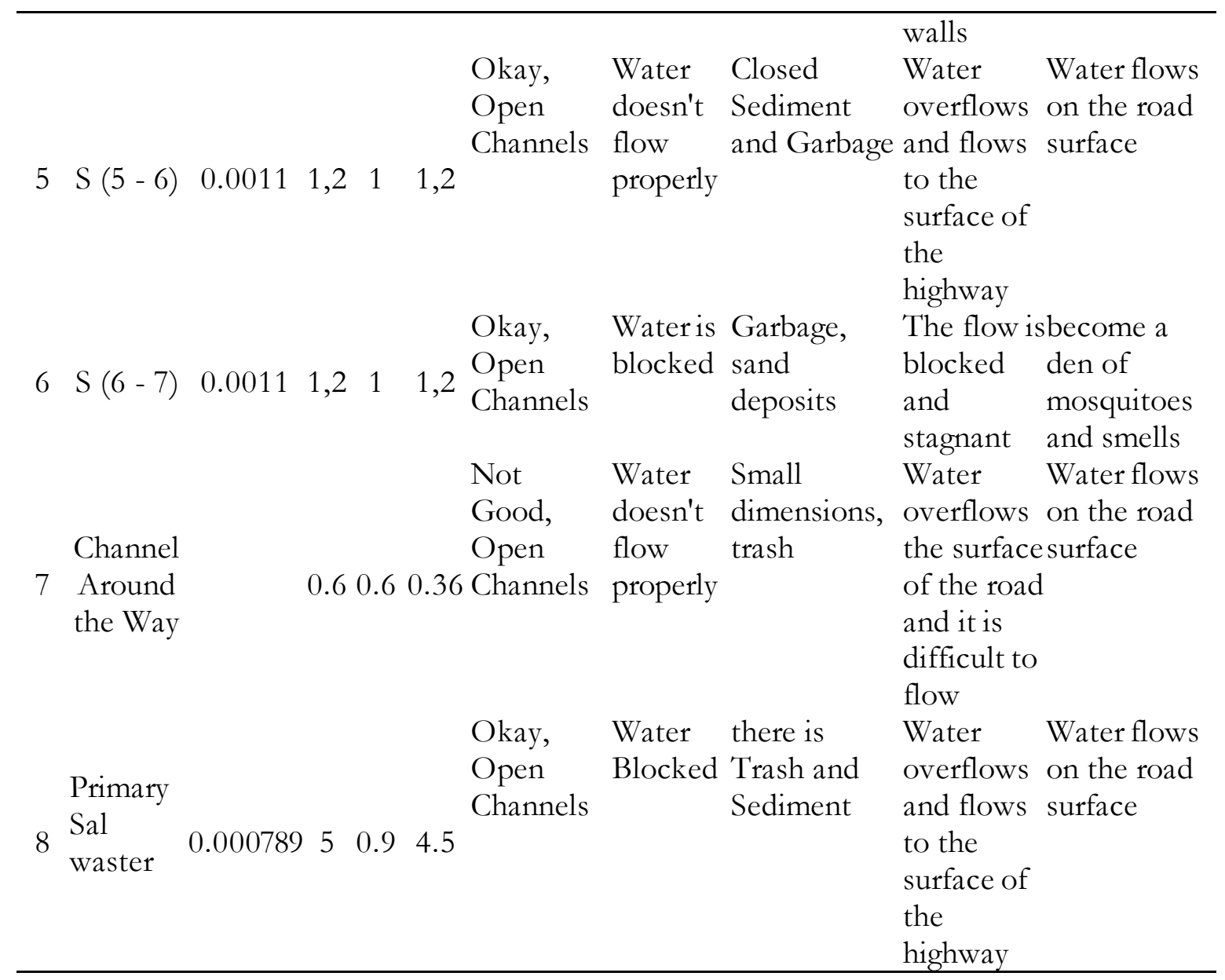

\section{Conclusion}

1. The Aceh Tamiang Kuala Simpang office area is a location with a fairly high degree of rainfall, namely with a rainfall intensity (I) of $126.432 \mathrm{~mm} /$ hour and a planned flood discharge for a 5-year return period, the result is $0.832 \mathrm{~m} 3 /$ second. And for the channel capacity in this primary drainage drainage is $0.829 \mathrm{~m} 3 /$ second, the value is smaller than the planned flood discharge $(\mathrm{Qr})$. so that in this case the channel capacity is still able to accommodate water flow but there are other factors that cause standing water or flooding, including sedimentation and silt in the drainage as well as lack of maintenance so that there is a large pile of garbage and grass in the drainage area.

2. As for the secondary waster channel, the calculation results for rainfall intensity (I) are $126.432 \mathrm{~mm} /$ hour. The planned flood discharges (Qr) for the 5-year return period is $2.551 \mathrm{~m} 3 /$ second and the value for the channel discharge capacity (Qs) is the result of the calculation of $2.216 \mathrm{~m} 3$ / second. This value is smaller than the planned flood discharge value, so that in this case the channel capacity is still able to accommodate water flow but there are other factors that cause standing water or flooding, including sedimentation and silt in the drainage as well as lack of maintenance so that there are many piles of garbage and grass in the drainage area.

3. The low topography of the Aceh Tamiang Kuala Simpang office area or a basin area with a height of 0-5 meters makes water gather inundate at certain road points and the lack of an inlet channel that connects the water flow from the pavement to the road drainage channel and the direction of the flow is not going well. Likewise, the awareness of the surrounding 
community in maintaining environmental cleanliness and regular maintenance of channels is still lacking.

\section{References}

Badan Pusat Statistic. Kecamatan Kota Kuala Simpang Dalam Angka 2018

Berli Ardian, Riko. (2016). Studi System Drainase di Fakultas Teknik Universitas Lampung. Unila Offset. Bandar Lampung.

Isnaini, et al. (2020). The Models of North Sumatra Provincial Government Policy in Resolving the Ex-Hgu Land Conflicts of PTPN II Plantations in Deli Serdang Regency. Budapest International Research and Critics Institute-Journal (BIRCI-Journal). P. 12061215.

Hasibuan, A. et al. (2020). The Analysis of the Effect of Determinant Factors of Palm Oil Plantation Sector on Agricultural Sector Growth in North Sumatera. Budapest International Research and Critics Institute-Journal (BIRCI-Journal). P. 1083-1094

Kamiama, Imade.(2015). Teknik Perhitungan Debit Rencana Bangunan Air. Yogyakarta: Graha Ilmu.

Kementrian Pekerjaan Umum. (2014). Peraturan Menteri Pekerjaan Umum No. 12 Tahun 2014 tentang Penyelenggaraan Sistem Drainase Perkotaan

Mulyono. (2011).Evaluasidan Perencanaan Sistem Drainase yang Berwawasan Lingkungan Kampus Universitas Lampung. Unila Offset.Bandar Lampung.

Sarisa, L.D. (2017). Analisis Spasio-Temporal Hujan Rancangan dan Hujan Rerata di Provinsi Lampung. Bandar Lampung : Universitas

Info Teknik Volume 14 No. 2 Desember. (2013). (126-136) Studi Drainase Berwawasan Lingkungan Untuk Jalan Pangeran Antasari Banjarmasin Holdani

Hendratta, Liany Amelia. (2016). Optimalisasi Sistem Jaringan Drainase Jalan Raya Sebagai Alternatif Penanganan Masalah Genangan Air. Universitas Sam Ratulangi. Manado.

Titah, Kreshna Eka Madani. (2013). Evaluasi Saluran Drainase Pada Jalan Pasar I Di Kelurahan Tanjung Sari Kecamatan Medan Selayang (Studi Kasus) .[Skrispsi]. Medan : Fakultas Teknik, Universitas Islam Sumatera tara.

Van Rafi'i. (2013). Analisis Geospasial Perubahan Tata Guna Lahan Terhadap Daerah Aliran Sungai Way Kuripan Lampung. Bandar Lampung

Kementerian PU Pengairan. (2013). Kriteria perncanaan irigasi. ( KP1) tentang perencanaan jaringan irigasi

Kementerian PU Pengairan. (2013). Kriteria perncanaan irigasi. ( KP2) tentang perencanaan saluran dan irigasi 